\title{
MULTIMEDIA LEARNING DENGAN GAME ENGINE CONSTRUCT 2 (GAME BUBBLE CLICK UNTUK LATIHAN MEMBACA)
}

\author{
Roro Santi \\ Politeknik LP3I \\ email: rorosanti@plb.ac.id
}

\begin{abstract}
Abstrak : Mengutip pernyataan Dr. Mubiar Agustin, M,Pd., dalam bukunya yang berjudul Mengajar yang menyenangkan dan bermakna bagi anak, sebagai kiat sukses menyiapkan, membuka dan menyampaikan inti dan menutup pembelajaran. Belajar yang menyenangkan dan bermakna akan memberikan dampak psikologis yang positif kepada anak didik. Menjadi sumber energi yang membangkitkan semangat, gairah, kebahagiaan dan inspirasi. Serta kreativitas anak akan berkembang pada situasi yang bebas dari tekanan". Bermain game adalah hal yang paling banyak dilakukan dalam kondisi belajar dirumah saat ini. Pembelajaran secara daring juga sudah dilakukan oleh semua tingkatan sekolah termasuk PAUD. Melalui penelitian ini penulis tertarik untuk memberikan salah satu cara membuat game edukasi sebagai perangkat ajar anak PAUD dalam mengenal huruf-huruf sebagai dasar belajar membaca. Diharapkan kedepannya dapat dijadikan sebagai salah satu referensi membuat aplikasi tanpa ngoding dan mudah bagi tenaga pendidik. Penulis mengunakan aplikasi game engine dari Scirra, London yaitu Construct 2 versi gratis, bisa upgrade menggunakan versi berbayar yaitu Construct 3. Sebagai langkah awal menumbuhkan ketertarikan membuat game versi sendiri, dan memanfaatkannya sebagai media pembelajaran.
\end{abstract}

Kata Kunci : Belajar, Multimedia, Game Edukasi

\section{Pendahuluan}

Mengutip pernyataan Dr. Mubiar Agustin, M,Pd., dalam bukunya yang berjudul Mengajar yang menyenangkan dan bermakna bagi anak, sebagai kiat sukses menyiapkan, membuka dan menyampaikan inti dan menutup pembelajaran. Belajar yang menyenangkan dan bermakna akan memberikan dampak psikologis yang positif kepada anak didik. Menjadi sumber energi yang membangkitkan semangat, gairah, kebahagiaan dan inspirasi. Serta kreativitas anak akan berkembang pada situasi yang bebas dari tekanan." Hal ini merupakan persiapan awal yang harus dimiliki oleh setiap pendidik bahwa belajar dan mengajar haruslah menyenangkan. Selain persiapan awal sebagai pembentukan dasar mental belajar dan menjadi tujuan dari belajar. Persiapan materi juga menjadi hal penting, karena materi yang disampaikan akan menjadi bahan pelajaran dan menjadi ukuran dalam penilaian proses belajar. Alat pendukung materi juga bisa menjadi hal yang menambah dosis menyenangkan dalam proses belajar. Seperti penggunaan musik dan film dapat menambah situasi yang berbeda dalam belajar. Terlebih anak-anak sekarang lebih dekat dengan gadget. Mengenalkan perangkat komputer secara positif untuk anak-anak pada usia dini dapat memberikan pengetahuan bahwa, penggunaan gadget harus memiliki tujuan-tujuan tertentu dengan batas-batasan tertentu juga. Hal ini terkadang lupa disampaikan oleh para orangtua. Para orangtua lebih sering mencari cara bagaimana mengurangi intensitas interaksi anak dengan gadget. Tanpa membekali anakanak pengetahuan sisi positif dan aturan bagaimana gadget digunakan.

Salah satu penyebab kenapa gadget begitu menarik adalah multimedia yang terdapat pada gadget. Multimedia yang interaktif dapat memberikan kesan menyenangkan untuk para 
penggunanya, tidak hanya orang tua anak-anak juga sangat menyukainya. Pemanfaatan multimedia sebagai media pembelajaran bisa menjadi salah satu solusi untuk merangkul minat anak-anak terhadap penggunaan gadget. Sambil mengenalkan ketertarikan bagaimana jika anak-anaklah yang dapat membuat aplikasi-aplikasi dalam gadget tersebut, tentu akan lebih menyenangkan. Bermain game adalah hal yang paling banyak dilakukan dalam kondisi belajar dirumah saat ini. Pembelajaran secara daring juga sudah dilakukan oleh semua tingkatan sekolah termasuk PAUD. Dunia pendidikan harus mulai membenahi diri menerapkan konsep daring dalam setiap kegiatannya. Dari mulai pemberian informasi secara online, administrasi online bahkan pembelajaran online.

Dalam pembelajaran online ini tentu saja, harus diiringi dengan pembenahan kemampuan sumber daya pendidik. Pendidik harus dipaksa untuk mengenal bagaimana memanfaatkan media digital sebagai perangkat pembelajaran. Tentu saja hal ini bukan hal mudah yang bisa dilakukan dalam waktu singkat. Tapi bisa dimulai dengan membuat perangkat ajar dengan menggunakan aplikasi-aplikasi yang minim pemrograman bahkan tidak harus menguasai bahasa pemrograman namun membuat aplikasi tetap bisa dilakukan sendiri oleh tenaga pendidik sebagai alat pendukung bahan ajar.

Melalui penelitian ini penulis tertarik untuk memberikan salah satu cara membuat game edukasi sebagai perangkat ajar anak PAUD dalam mengenal huruf-huruf sebagai dasar belajar membaca. Diharapkan kedepannya dapat dijadikan sebagai salah satu referensi membuat aplikasi tanpa ngoding dan mudah bagi tenaga pendidik.

Penulis mengunakan aplikasi game engine dari Scirra, London yaitu Construct 2 versi gratis, bisa upgrade menggunakan versi berbayar yaitu Construct 3. Sebagai langkah awal menumbuhkan ketertarikan membuat game versi sendiri, dan memanfaatkannya sebagai media pembelajaran.

\section{Bahan dan Metode}

Construct 2 adalah tools pembuat game berbasis HTML5. Construct 2 tidak menggunakan bahasa pemrograman khusus, jadi untuk untuk mengembangkan game dengan Construct 2 pengguna tidak perlu mengerti bahasa pemrograman yang relatif lebih rumit dan sulit [2]. Untuk download aplikasi bisa klik : https://www.scirra.com/construct2/releases.

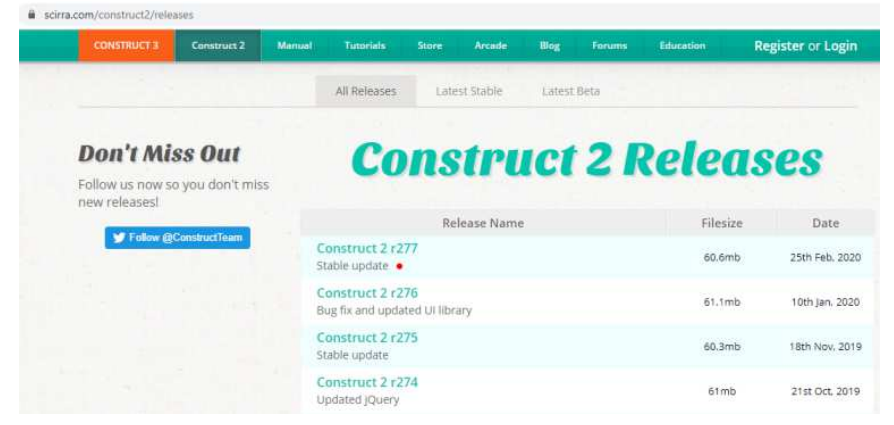

Gambar 1. Link untuk download aplikasi Construct 2

a. Spesifikasi Minimum 
Berikut ini spesifikasi minimum yang digunakan untuk membuat game dengan Construct 2, antara lain [2] :

1) Prosesor $1 \mathrm{GHz}$.

2) Memori 512 MB RAM.

3) Windows XP SP3 ke atas - 32 bit.

4) Graphic Card

b. Cara Instal Contruct 2

Sebagai referensi, cara instal construct 2 berdasarkan buku game mobile learning [2] (Construct 2 Free versi r250, yang digunakan penulis adalah versi r277) :

1) "Dobel Klik" Software Construct 2 yang telah di download dari website Scirra.

construct2-r250-setup.exe
Construct 2 Setup

2) Klik "accept" dan tekan "Next".

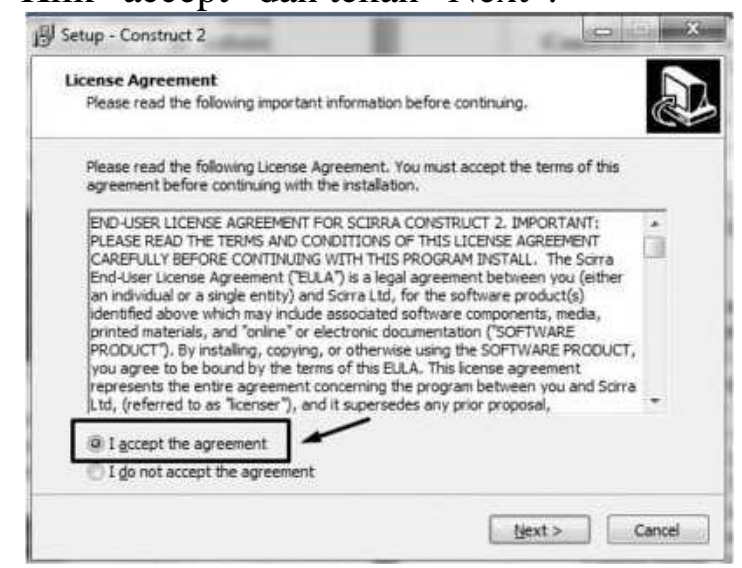

3) Klik "Next" saja terus sampai ada tombol "Install". Klik "Install" untuk memulai proses instalasi.

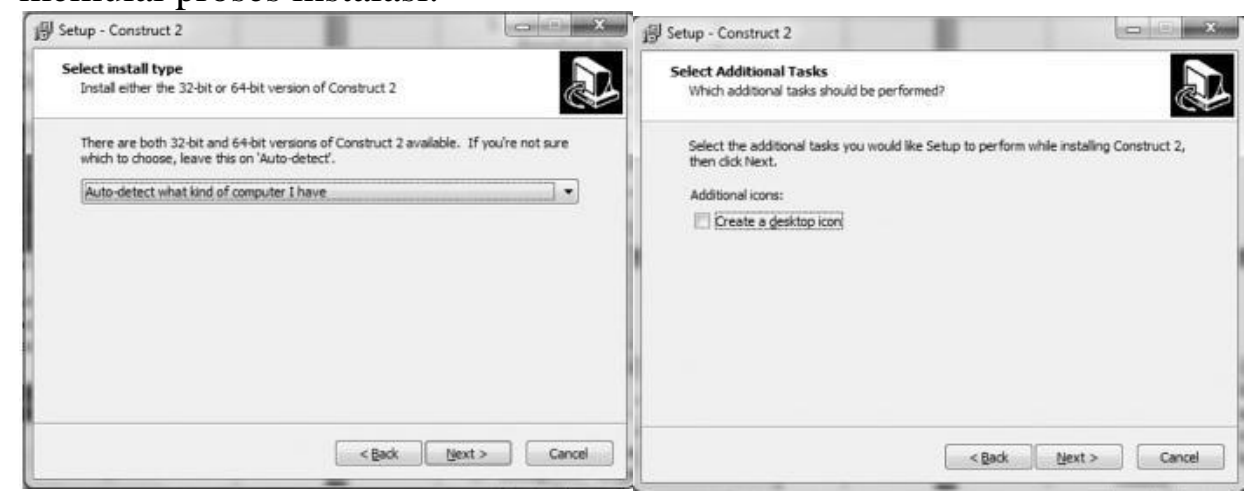




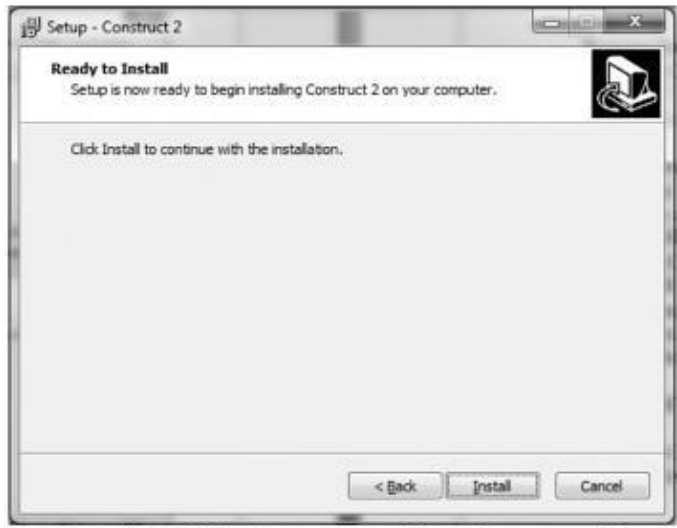

4) Setelah selesai menginstall, klik "Finish" untuk memulai menggunakan Construct 2.

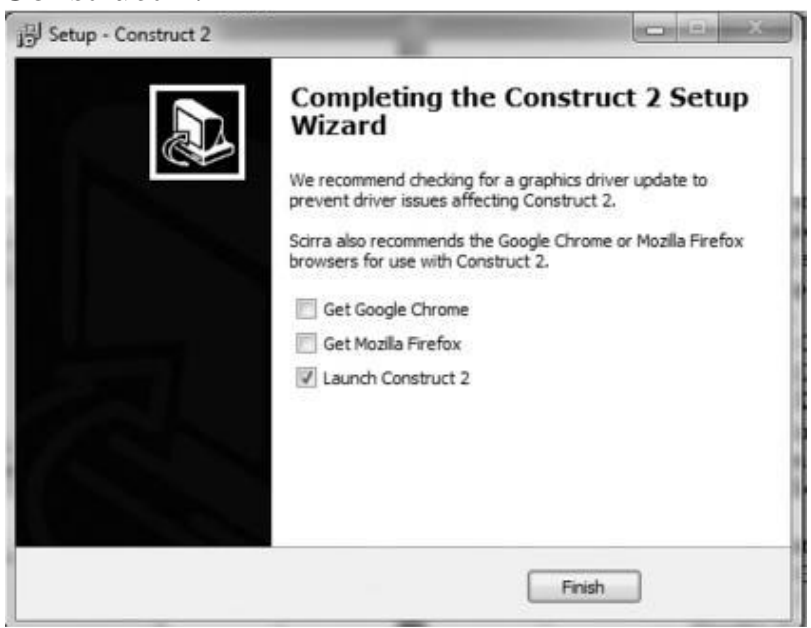

5) Layout aplikasi construct 2 yang sudah terinstal di laptop penulis (versi r277) :

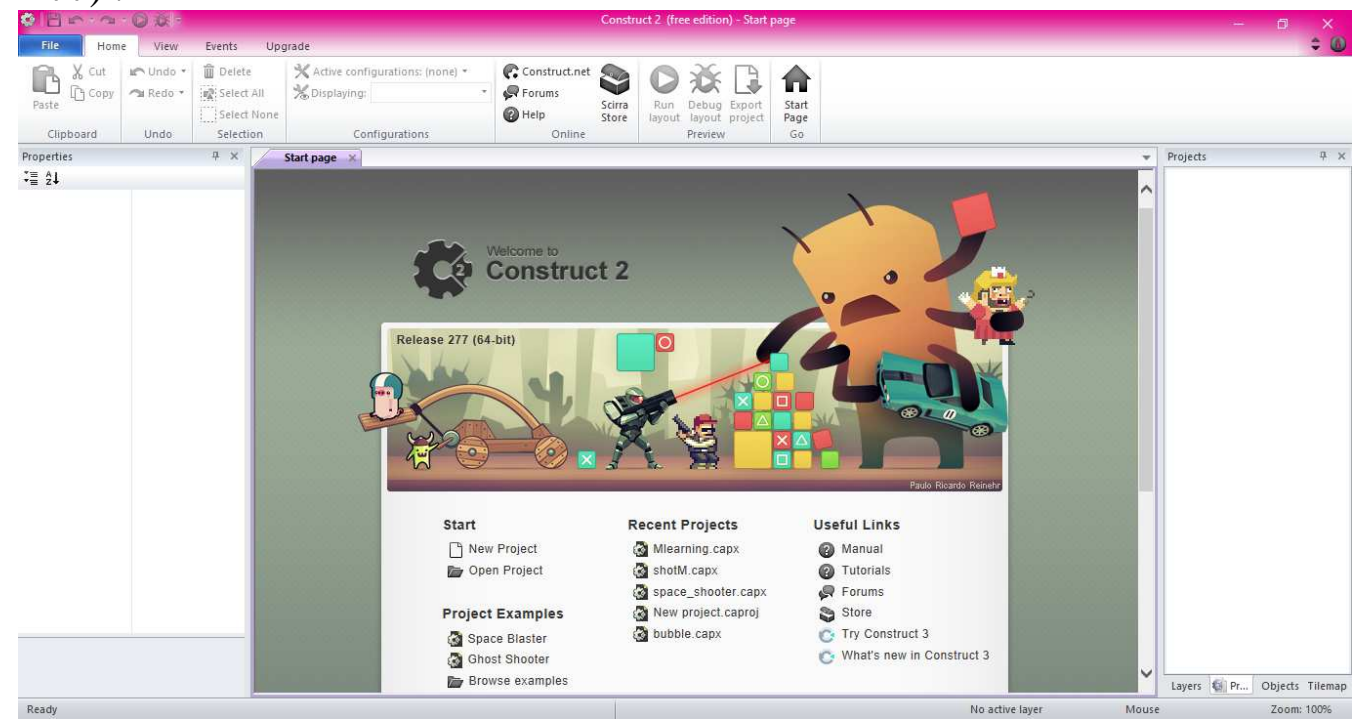

\section{Hasil Penelitian}

a. Proses Pembuatan Game Click Buble

Berikut ini langkah membuat project yaitu membuat game click bubble yang sudah dilakukan oleh penulis.

1) File $>$ New Project atau Klik New Project di Start Page : 


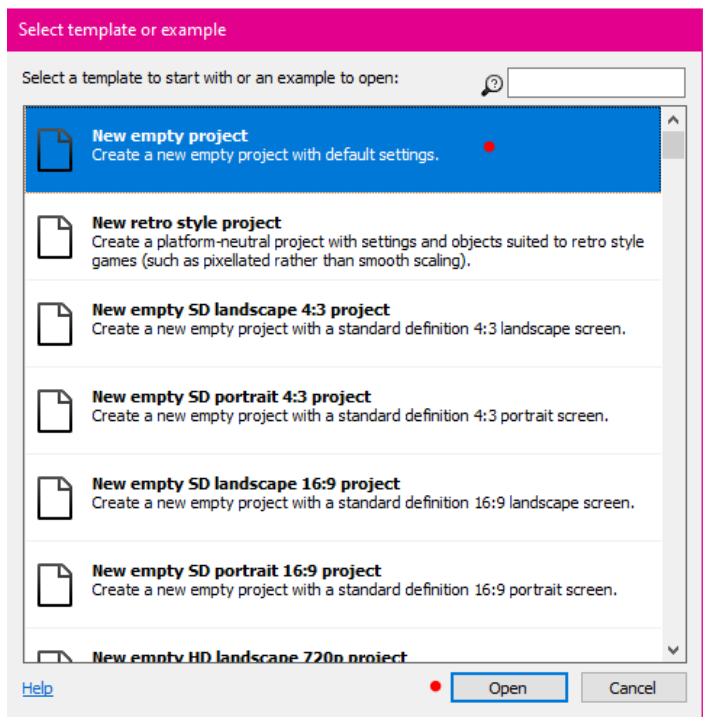

2) Layout dan Window size $=854 \times 480$ pixel

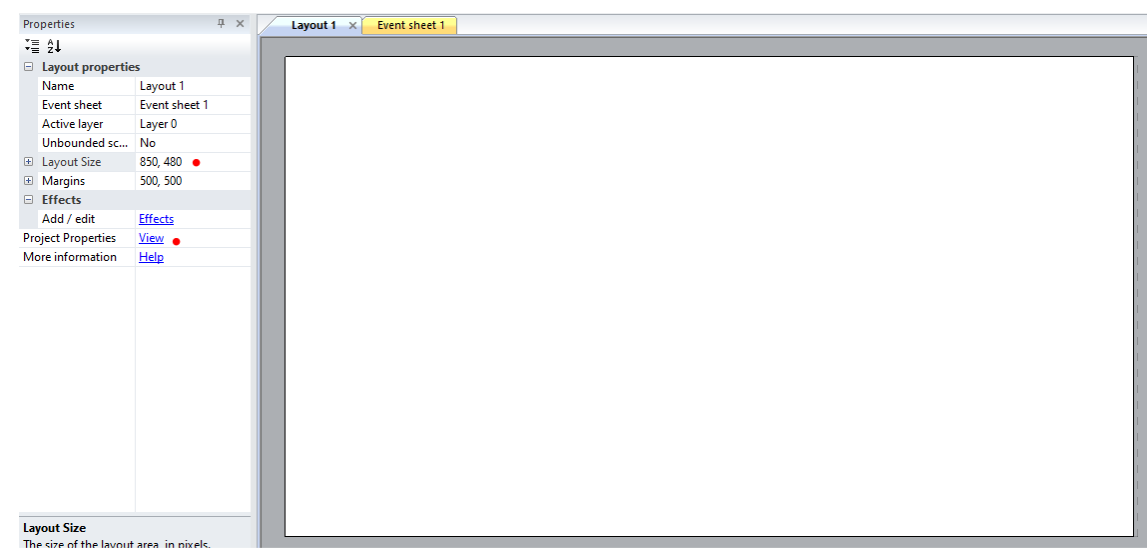

3) Untuk layout hasil running penulis menggunakan NW.js

\begin{tabular}{|c|c|c|}
\hline \multicolumn{3}{|c|}{ Configuration Settings } \\
\hline & Preview browser & NW.js • \\
\hline & Fullscreen in brow... & Letterbox scale \\
\hline & Fullscreen scaling & High quality \\
\hline & Use high-DPI displ... & Yes \\
\hline & Orientations & Any \\
\hline & Enable WebGL & On \\
\hline & Sampling & Linear \\
\hline & Downscaling & Medium quality \\
\hline & Physics engine & Box2D asm.js \\
\hline & Loader style & Construct 2 splash \\
\hline & Preload sounds & Yes \\
\hline & Pause on unfocus & No \\
\hline & Clear background & Yes \\
\hline
\end{tabular}

4) Instal terlebih dahulu NW.js (download di : https://www.scirra.com/nwjs) 


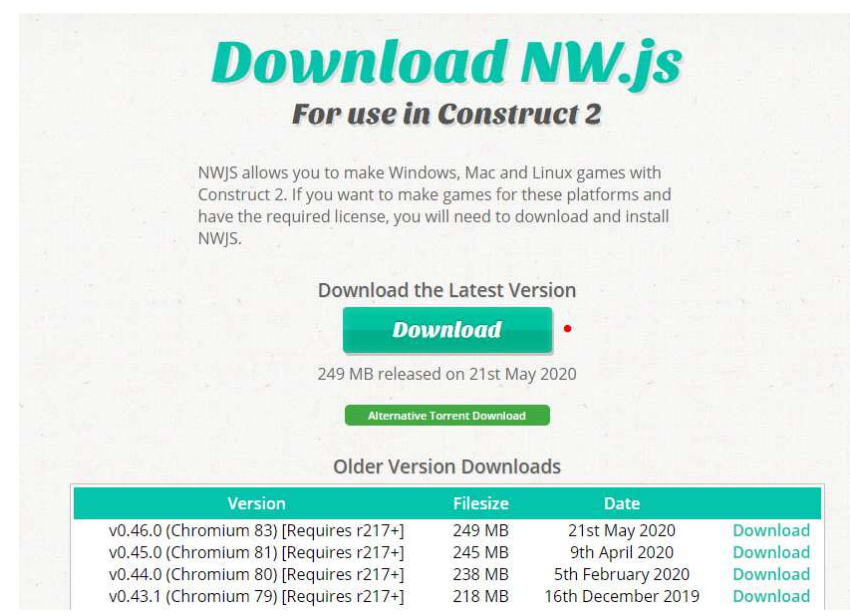

5) Object yang digunakan : (background, bubble, partikel letusan bubble, tombol close, text skor dan text target - tambahan image target, sebagai pemanis)

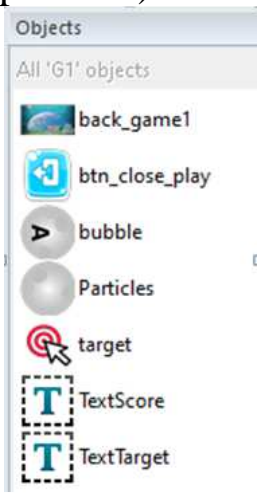

6) Objek background, penulis menggunakan aplikasi Picart pada smartphone kemudian melakukan edit size canvas atau image menggunakan aplikasi paint/paint 3D di laptop.

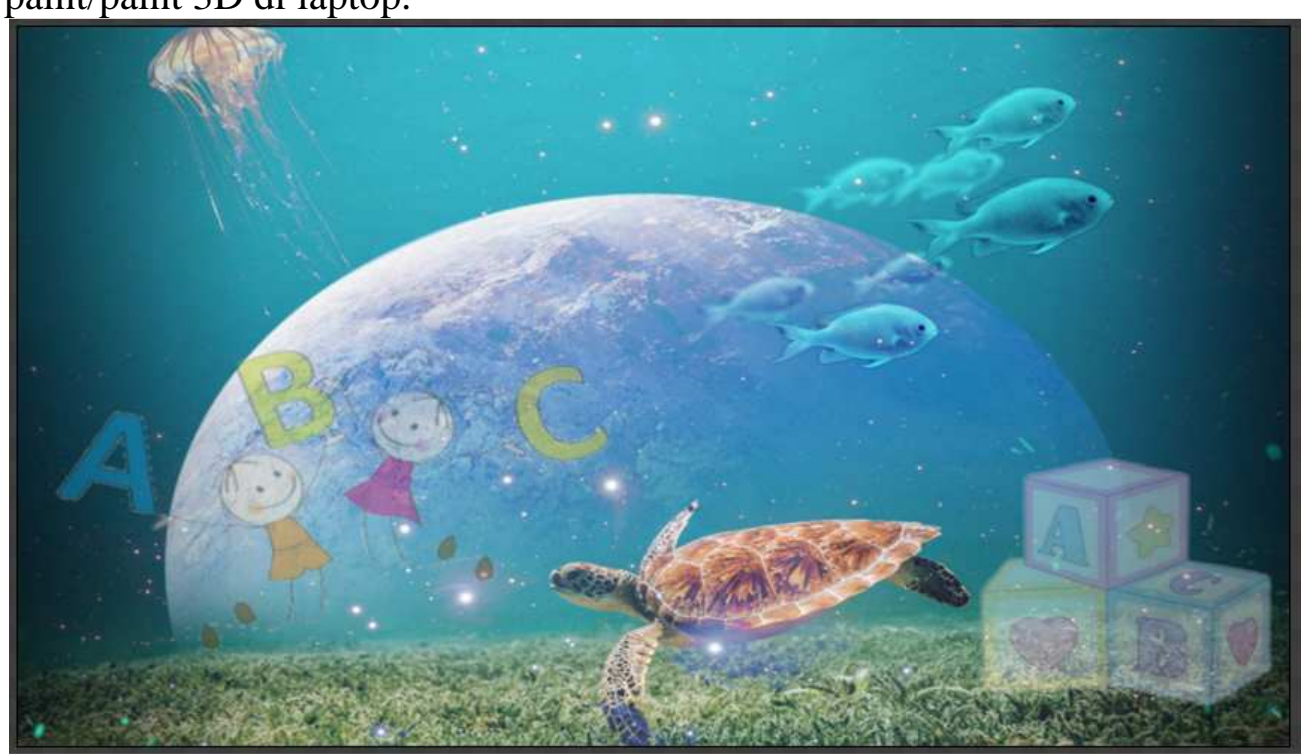

7) Objek bubble. merupakan objek gratis yang didownload penulis di websitewebsite aset objek game (yaitu website yang menyediakan aset background, tombol, sound dan lain-lain untuk digunakan dalam pembuatan game dengan construct 2). 


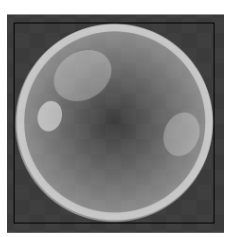

8) Karena objek yang akan diklik adalah bubble dengan huruf-huruf tertentu, maka dilakukan edit untuk image bubble dengan aplikasi Paint 3D.

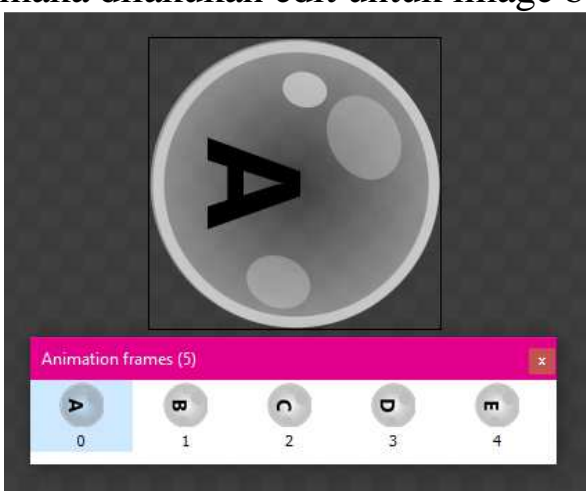

9) Behaviors bubble :

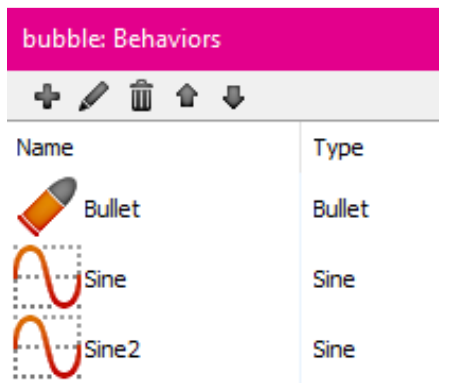

10) Properties bubble :

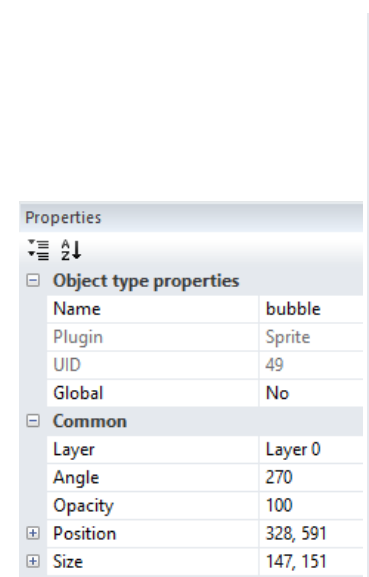

11) Objek Text skor :

\begin{tabular}{l|l} 
Behaviors \\
$\square$ Bullet \\
\hline Speed & 100 \\
\hline Acceleration & 0 \\
\hline Gravity & 0 \\
\hline Bounce off solids & No \\
\hline Set angle & Yes \\
\hline Initial state & Enabled \\
\hline Sine & \\
\hline Active on start & Yes \\
\hline Movement & Width \\
\hline Wave & Sine \\
\hline Period & 1 \\
\hline Period random & 0 \\
\hline Period offset & 0 \\
\hline Period offset random & 0 \\
\hline Magnitude & 5 \\
\hline Magnitude random & 0 \\
\hline
\end{tabular}

12) Objek Text target :

\begin{tabular}{|l|l|}
\hline Sine2 & \\
\hline Active on start & Yes \\
\hline Movement & Height \\
\hline Wave & Sine \\
\hline Period & 1.5 \\
\hline Period random & 0 \\
\hline Period offset & 0 \\
\hline Period offset random & 0 \\
\hline Magnitude & -5 \\
\hline Magnitude random & 0 \\
\hline Add / edit & $\underline{\text { Behaviors }}$ \\
\hline Effects & Normal \\
\hline Blend mode & $\underline{\text { Effects }}$ \\
\hline Add / edit & \\
\hline Container & $\underline{\text { Create }}$ \\
\hline No container & \\
\hline Properties & $\underline{\text { Edit }}$ \\
\hline Animations & $\underline{\text { Make 1:1 }}$ \\
\hline Size & Visible \\
\hline Initial visibility & Default \\
\hline Initial animation & 0 \\
\hline Initial frame & \\
\hline
\end{tabular}$$
0
$$ 


\begin{tabular}{|c|c|c|}
\hline \multirow[t]{5}{*}{ 日 } & \multicolumn{2}{|c|}{ Object type properties } \\
\hline & Name & TextScore \\
\hline & Plugin & Text \\
\hline & UID & 51 \\
\hline & Global & No \\
\hline \multirow[t]{4}{*}{$\boxminus$} & Common & \\
\hline & Layer & Layer 0 \\
\hline & Angle & 0 \\
\hline & Opacity & 100 \\
\hline$\boxplus$ & Position & 0,0 \\
\hline$\boxplus$ & Size & 850,47 \\
\hline \multirow[t]{3}{*}{$\boxminus$} & Instance variables & \\
\hline & Score & 0 \\
\hline & Add / edit & Instance variables \\
\hline
\end{tabular}

\begin{tabular}{ll}
$\square$ & Instance variables \\
\hline Target & \\
\hline Add / edit & Instance variables \\
$\square$ Behaviors & \\
\hline $\begin{array}{l}\text { Add / edit } \\
\square\end{array}$ & Effects \\
\hline Blend mode & Normal \\
\hline Add / edit & Effects \\
$\square$ Container & \\
\hline No container & Create \\
$\square$ Properties & \\
\hline Text & A \\
\hline Initial visibility & Visible \\
\hline Font & Elephant(72) \\
\hline Color & $\square 255,255,255$ \\
\hline Horizontal align... & Center \\
\hline Vertical alignment & Center \\
\hline
\end{tabular}

13) Tambahkan sound water-splash, untuk efek ledakan bubble ketika di klik. Dan sound background.

14) Eventsheet :

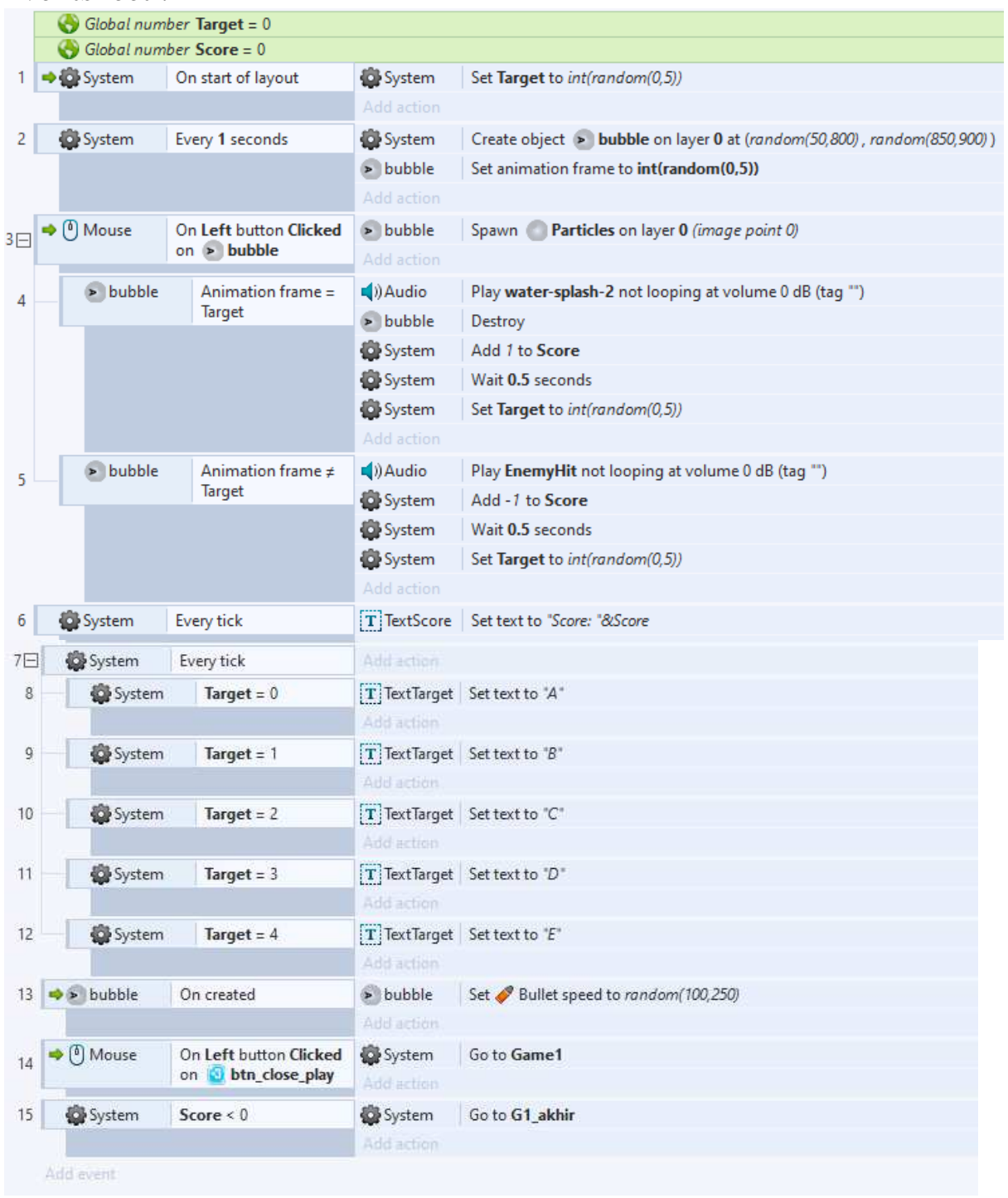

15) Menambahkan halaman game over : 


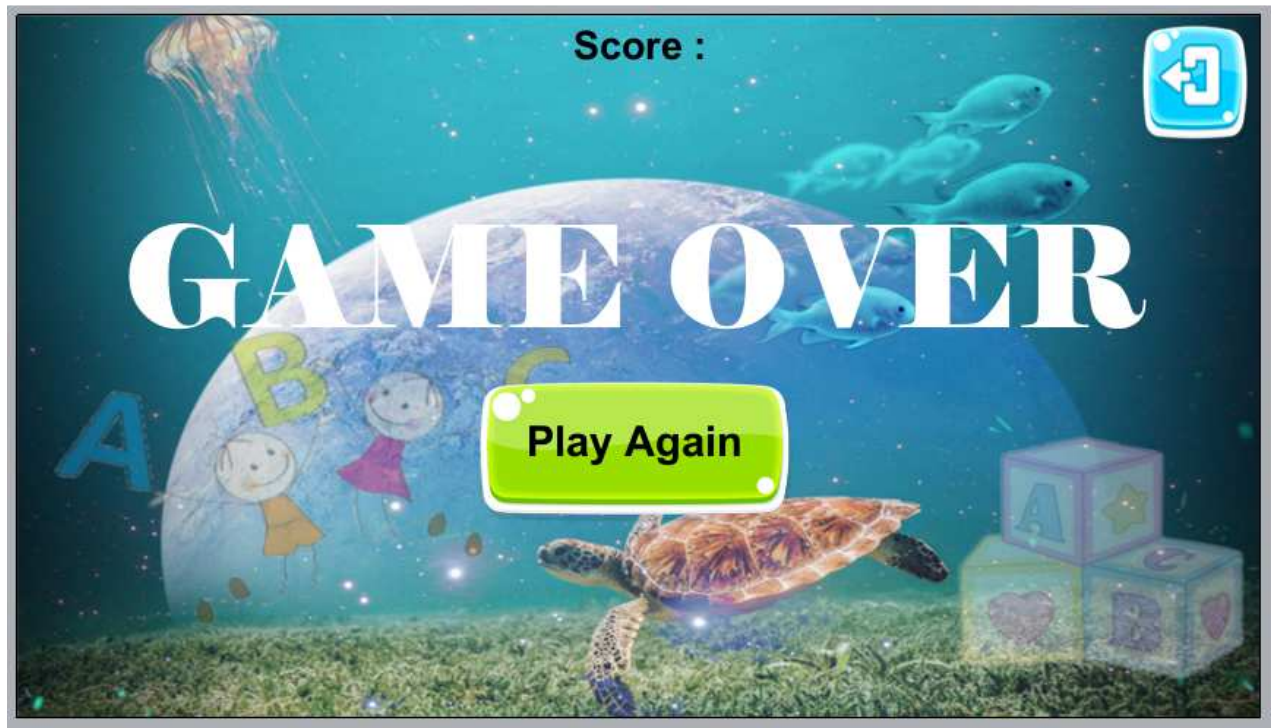

16) Objek di layout game over :

Objects
All 'G1_akhir' objects
back_game1
Tombol

17) Eventsheet game over :

\begin{tabular}{|c|c|c|c|c|}
\hline \multirow{2}{*}{\multicolumn{2}{|c|}{$1 \Rightarrow$ System }} & \multirow[t]{2}{*}{ On start of layout } & T] TextScore & \multirow[t]{2}{*}{ Set text to -1} \\
\hline & & & Add action & \\
\hline 2 & $\Rightarrow$ Mouse & $\begin{array}{l}\text { On Left button Clicked } \\
\text { on btn_close_play }\end{array}$ & Wystem & Go to Game1 \\
\hline \multirow[t]{3}{*}{3} & $\Rightarrow$ (1) Mouse & On Left button Clicked & System & Go to $\mathbf{G 1}$ \\
\hline & & & א్ System & Set Target to 0 \\
\hline & & & \$ System & Set Score to 0 \\
\hline
\end{tabular}

18) Lakukan Run layout:

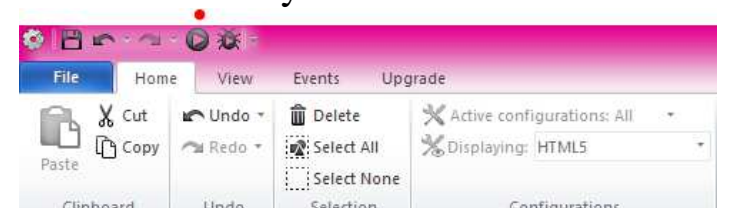

19) Tidak menutup kemungkinan apabila dilakukan modifikasi lebih luas pada game ini. Contohnya penulis membuat game ini kedalam bagian dari aplikasi perangkat ajar berbasis multimedia, yang secara keseluruhan materi perancangannya dijadikan sebagai salah satu modul praktikum di mata kuliah multimedia mobile.

20) Desain layout awal : 


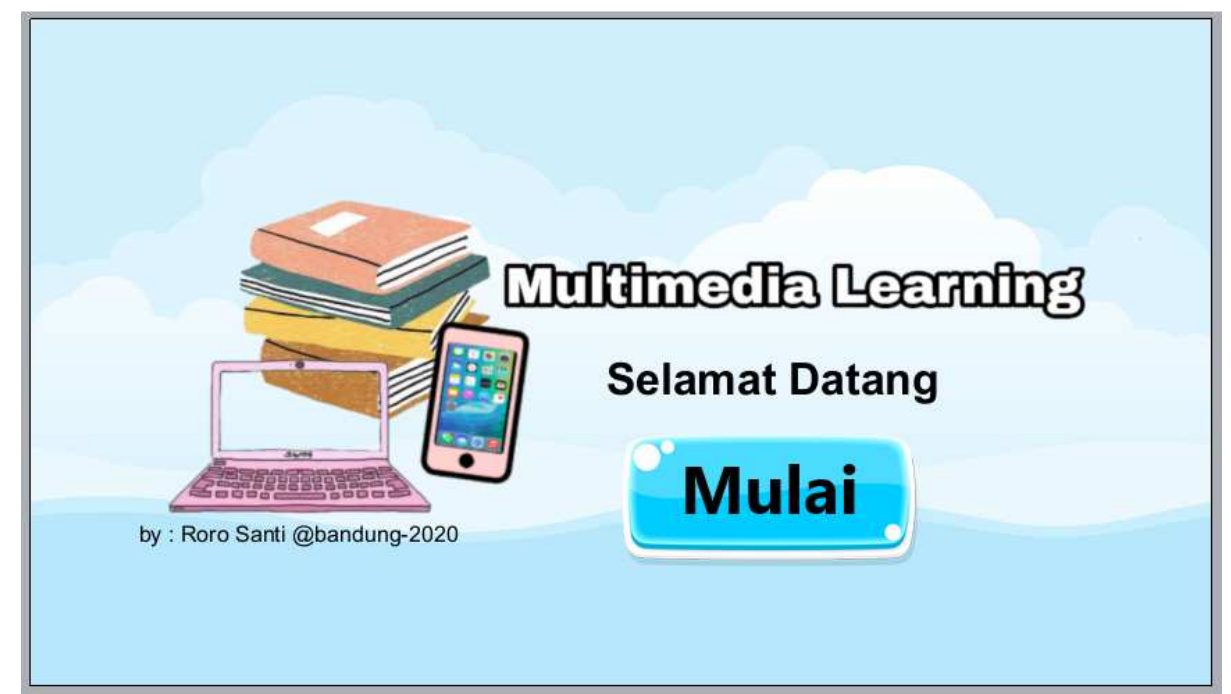

21) Eventsheet layout awal :

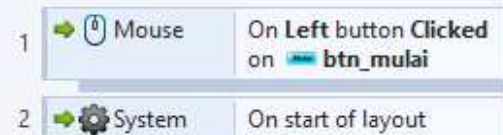

System

Go to Menu

22) Halaman menu :

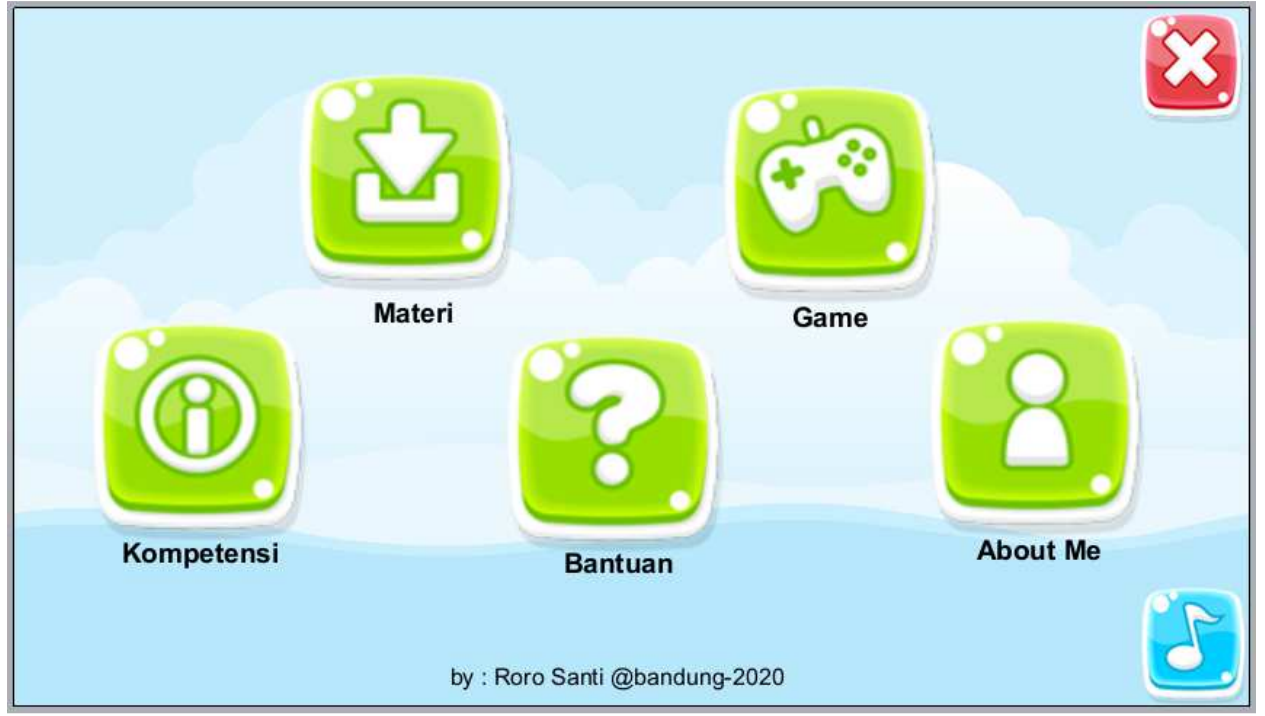

23) Eventsheet menu : 


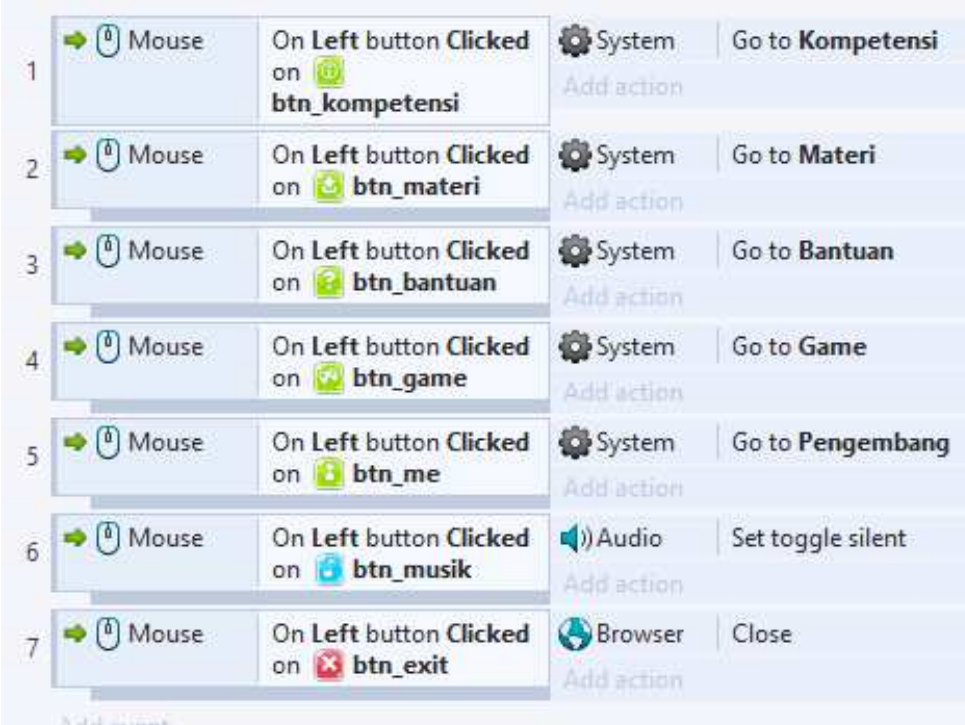

24) Halaman kompetensi, bantuan dan about me :

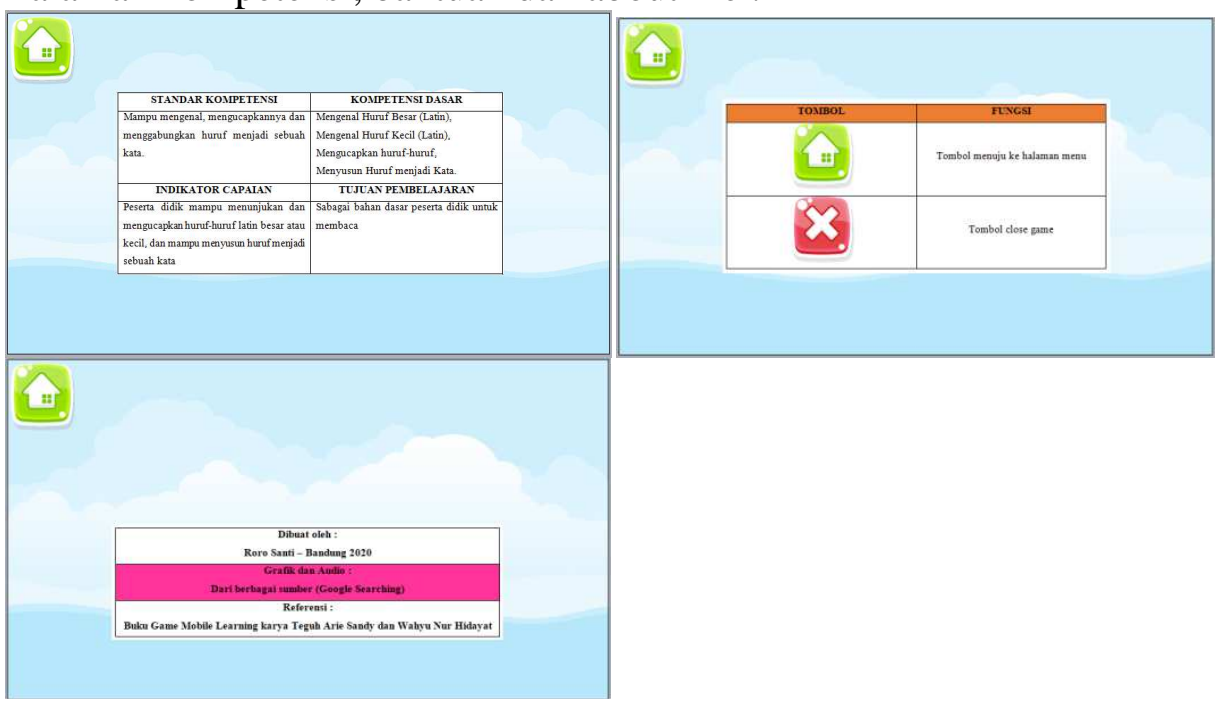

25) Eventsheet kompetensi, bantuan dan about me :

$1 \Rightarrow$ (1) Mouse $\begin{aligned} & \text { On Left button Clicked } \\ & \text { on bystem bome }\end{aligned}$ Go to Menu

26) Halaman Materi :

27) Objek dihalaman materi :

Objects


28) Objek slide_materi : (dibuat menggunakan power point kemudian disave sebagai image PNG untuk setiap slide-nya)

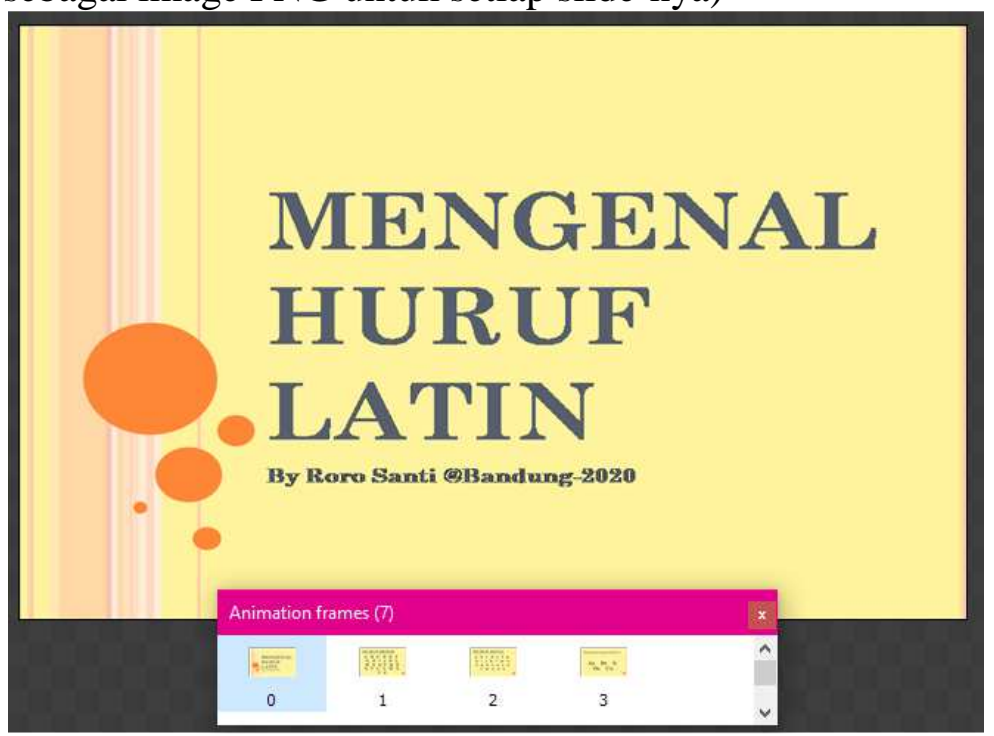

29) Eventsheet materi :

\begin{tabular}{|c|c|c|c|c|}
\hline 1 & $\Rightarrow 0$ Mouse & $\begin{array}{l}\text { On Left button Clicked } \\
\text { on b btn_next }\end{array}$ & F- slide_materi & Set animation frame to self.Animationframe +1 \\
\hline 2 & $\Rightarrow 0$ Mouse & $\begin{array}{l}\text { On Left button Clicked } \\
\text { on } 1 \text { btn_back }\end{array}$ & 10. slide_materi & Set animation frame to self.Animationframe-1 \\
\hline 3 & $\Rightarrow 0$ Mouse & $\begin{array}{l}\text { On Left button Clicked } \\
\text { on btn_home }\end{array}$ & System & Go to Menu \\
\hline
\end{tabular}

30) Halaman Game menu : (game 1 adalah bubble click, game 2 adalah menyusun huruf menjadi sebuah kata atau kalimat dan game ke 3 direncanakan untuk latihan mengenal sebuah kata atau kalimat dengan metode game adalah tembak. Atau dapat dilakukan modifikasi lainnya sesuai dengan tujuan materi, sehingga aplikasi ini akan menjadi sebuah aplikasi yang secara keseluruhan adalah sebuah game untuk satu materi pelajaran). 


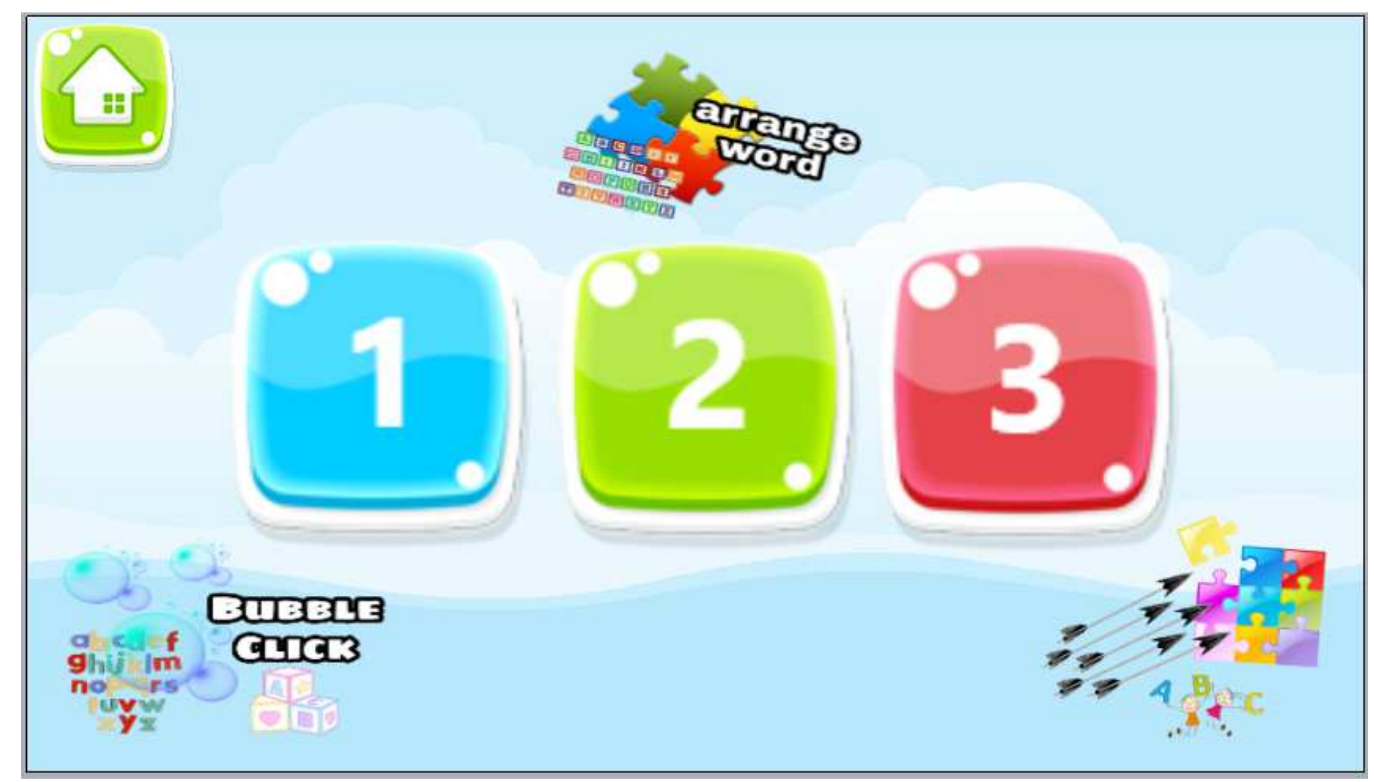

31) Eventsheet game menu :

\begin{tabular}{|c|c|c|c|}
\hline$\Rightarrow 0$ Mouse & $\begin{array}{l}\text { On Left button Clicked } \\
\text { on btn_home }\end{array}$ & 20 System & Go to Menu \\
\hline$\Rightarrow 0$ Mouse & $\begin{array}{l}\text { On Left button Clicked } \\
\text { on game1 }\end{array}$ & 203 System & Go to Game1 \\
\hline$\Rightarrow$ OMouse & $\begin{array}{l}\text { On Left button Clicked } \\
\text { on game2 }\end{array}$ & \& System & Go to Game2 \\
\hline$\Rightarrow 0$ Mouse & $\begin{array}{l}\text { On Left button Clicked } \\
\text { on game3 }\end{array}$ & \& System & Go to Game3 \\
\hline
\end{tabular}

32) Halaman game ke-2 :

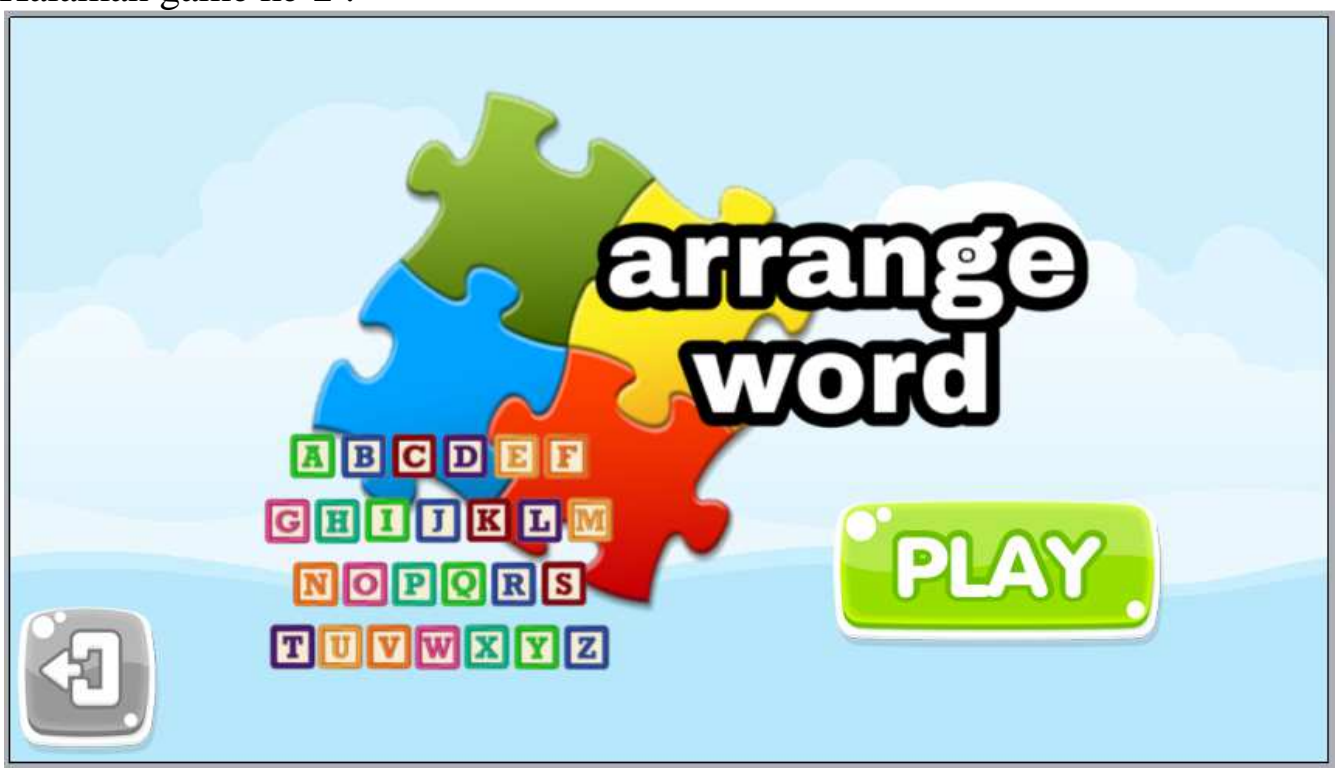

33) Halaman game ke-3, masih dalam proses dengan rencana game yang dibuat adalah game shooter sebuah kata.

34) Eventsheet game1,2 dan 3 : (tinggal diganti G1 dengan G2 dan G3) 


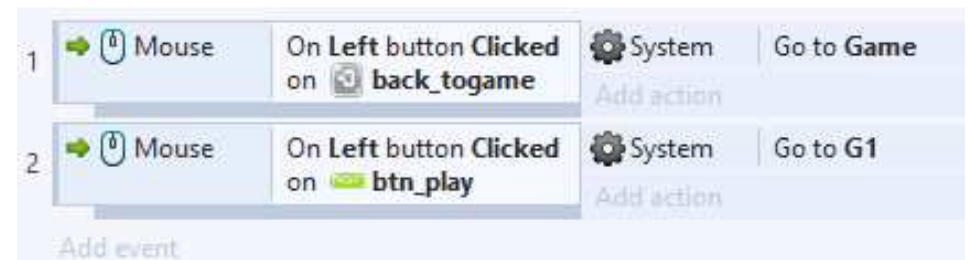

35) Isi dari proses perancangan game ke- 2 dan 3 masih dalam proses, karena sesuai judul yang dijadikan contoh pada penelitian ini adalah game bubble click.

\section{Implementasi}

Game bubble click ini diadaptasi dari Game bubble touch yang ada di buku "Game Mobile Learning". Dari buku referensi game bubble touch hanya sebagai hiburan semata untuk melatih ketangkasan penguna dalam memecahkan balon. Penulis melakukan modifikasi dengan cara klik karena versi gratis construct 2 tidak bisa melakukan build ke versi mobile. Sehingga game bubble click ini hanya bisa digunakan di perangkat laptop atau komputer desktop berbasis web. Atau bisa digunakan pada website secara online sebagai salah satu materi pembelajaran daring.

Modifikasi lainnya yaitu, pada bubble touch hanya memecahkan balon. Tapi pada bubble click yang dibuat penulis, klik dilakukan pada objek dengan target huruf tertentu. Dengan tujuan melatih ingatan pengguna pada suatu huruf abjad tertentu.

Berikut ini hasil implementasi / running project yang sudah dibuat oleh penulis :

a. Proses untuk mulai memainkan Game :

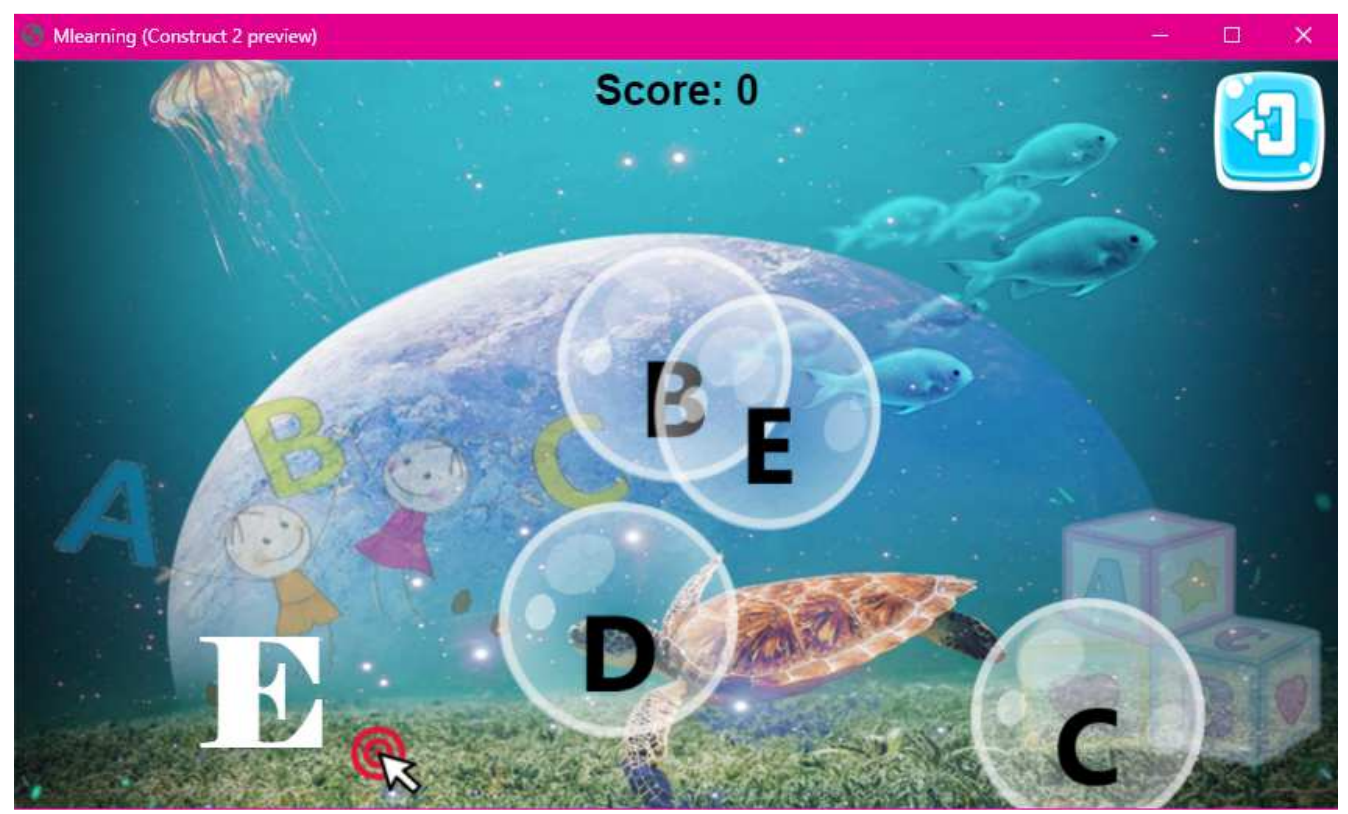


b. Game over karena terlalu sering melakukan kesalahan (skor -1) :

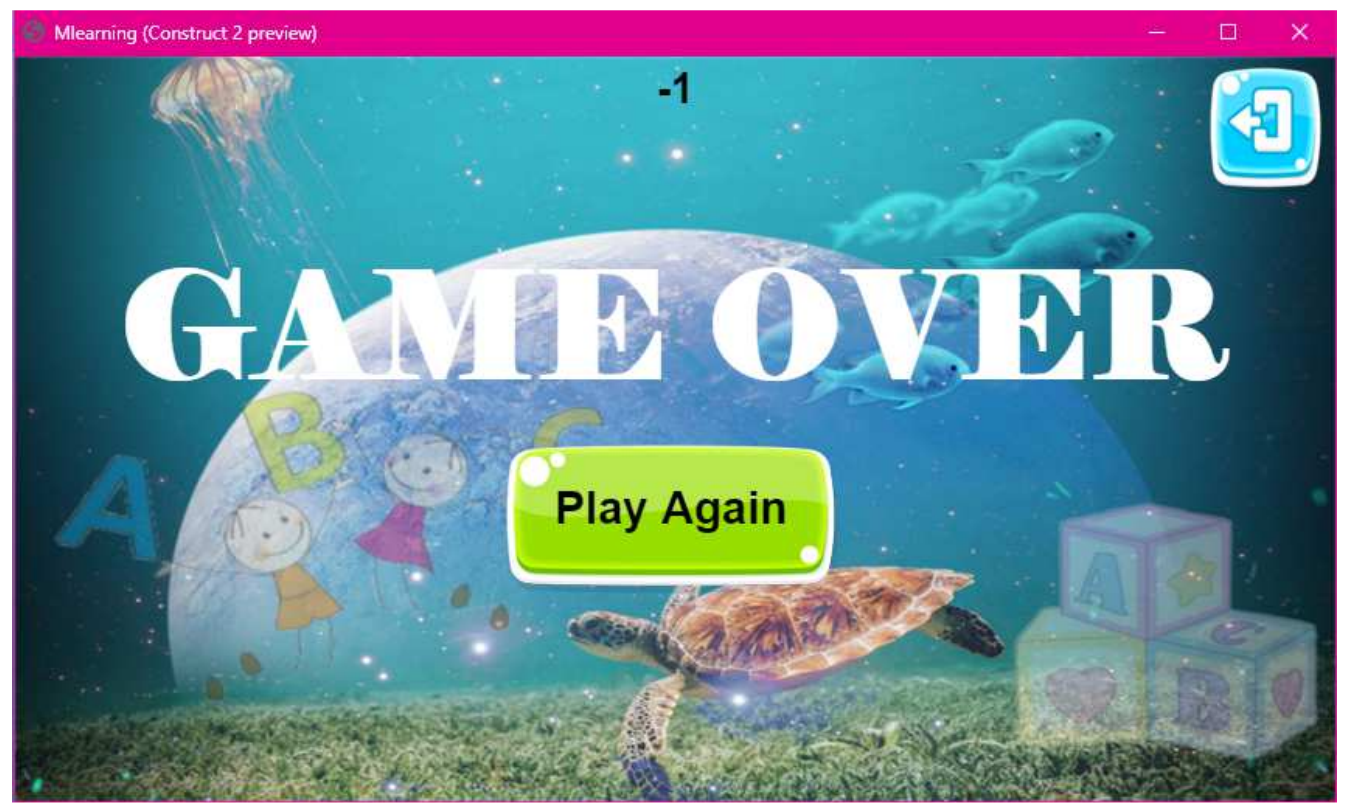

c. Secara keseluruhan layout multimedia learning ini adalah :

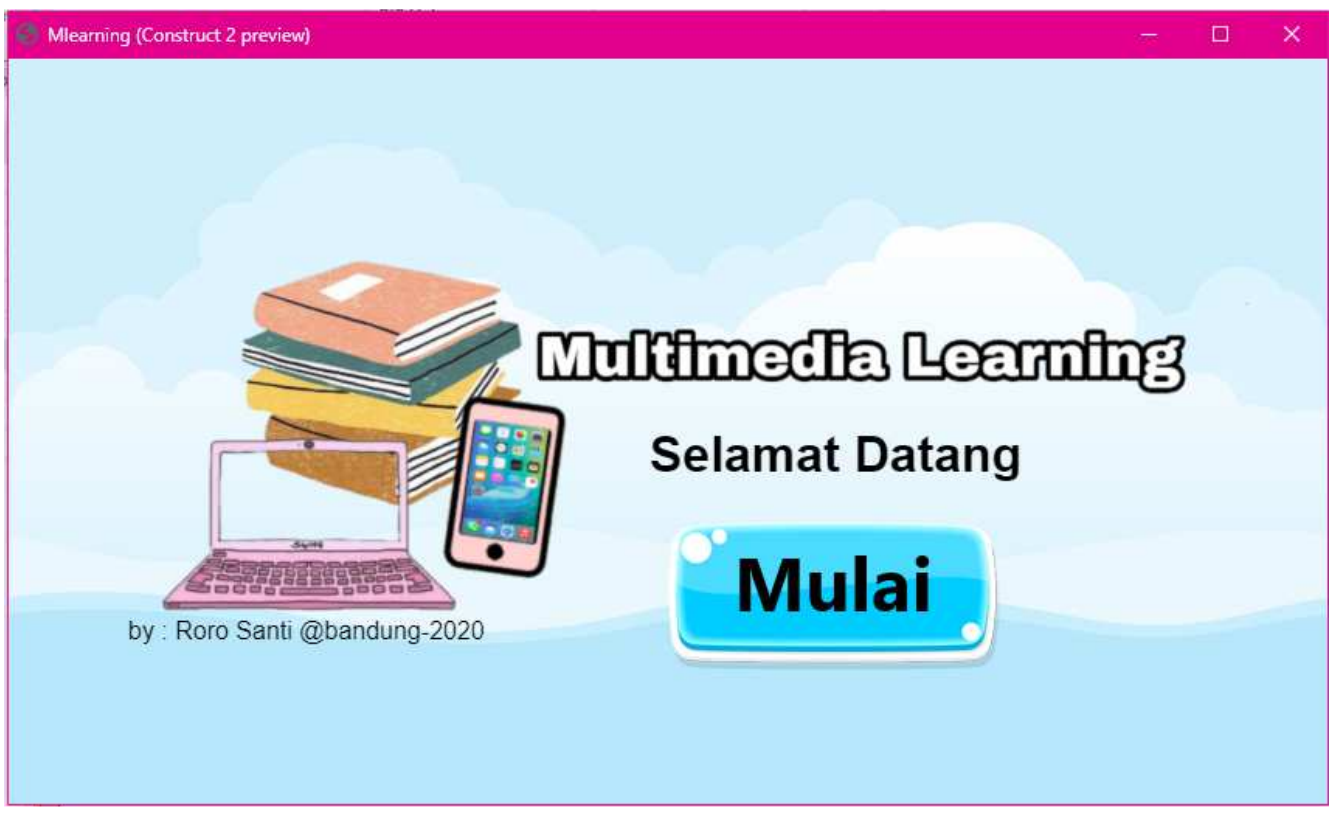

d. Halaman menu (dari klik mulai) : 


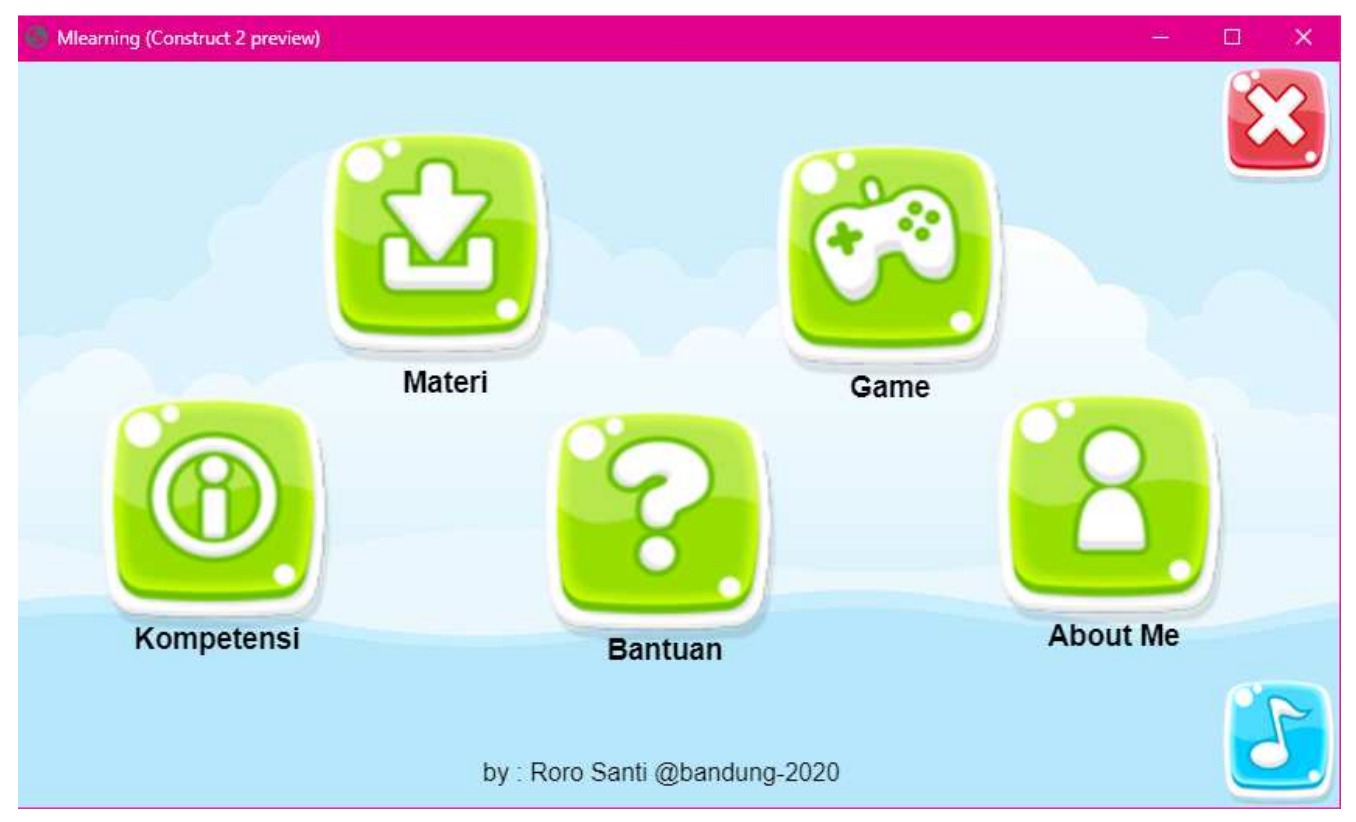

e. Halaman Kompetensi :

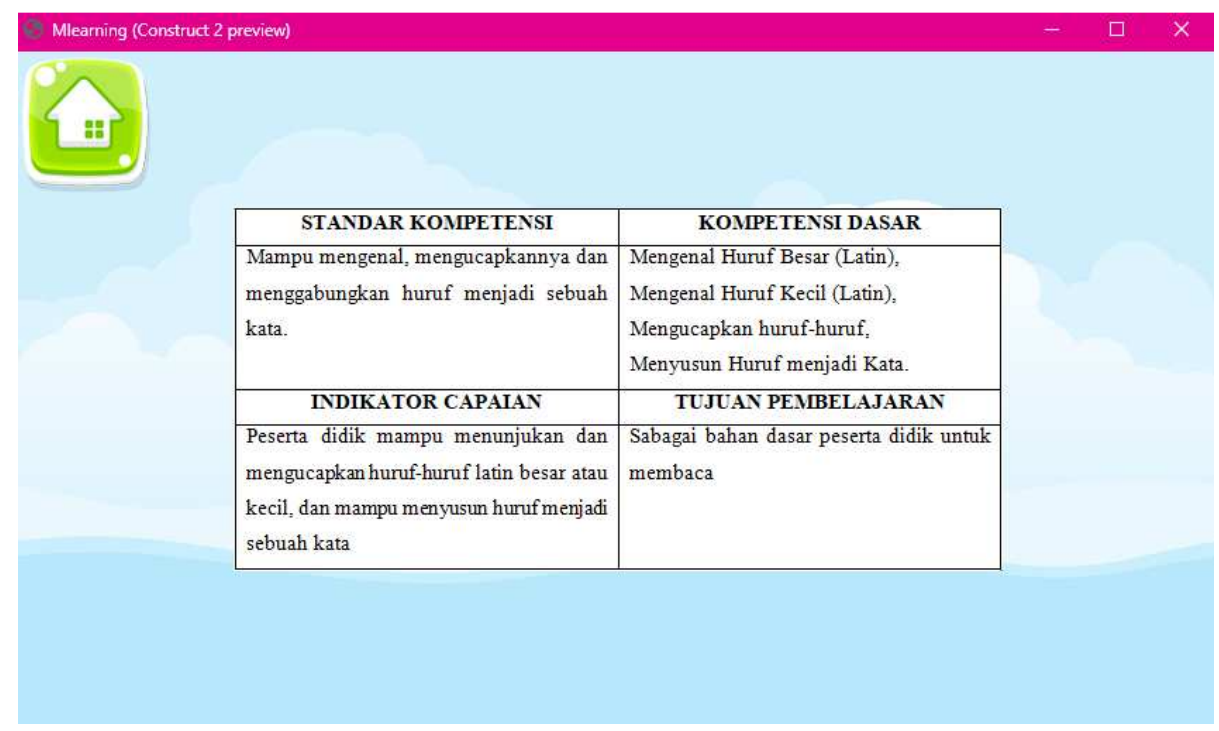

f. Halaman Materi :
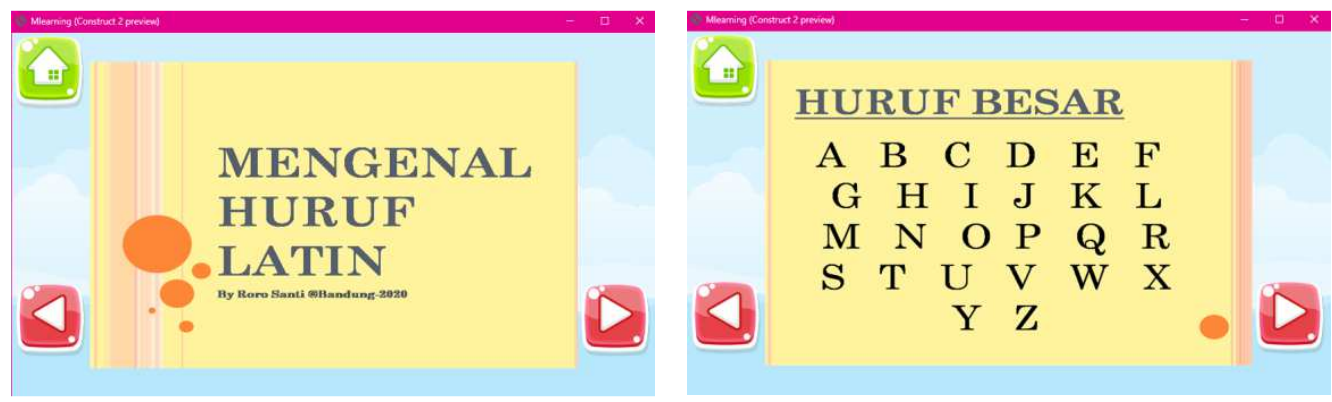


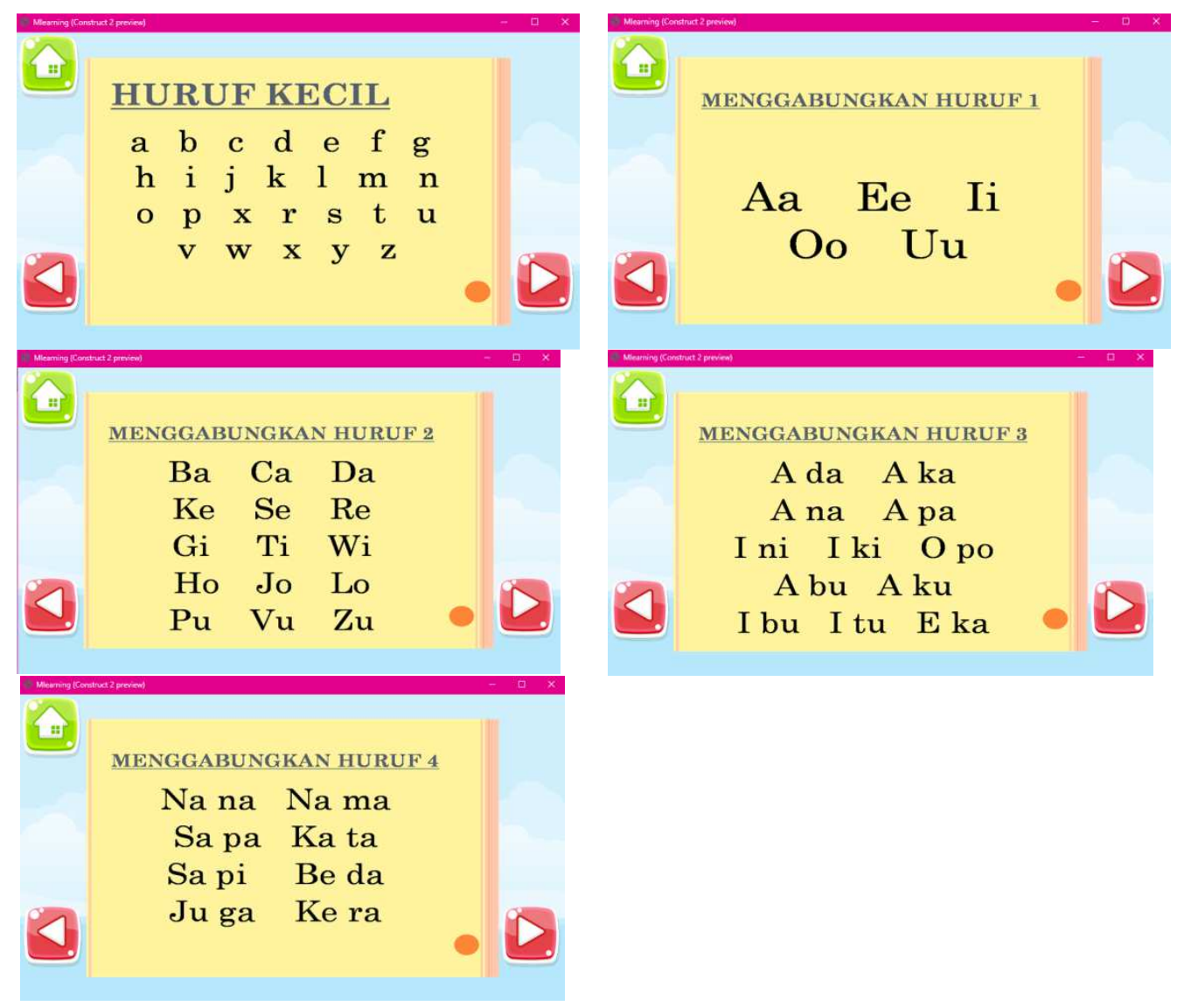

g. Halaman Bantuan :

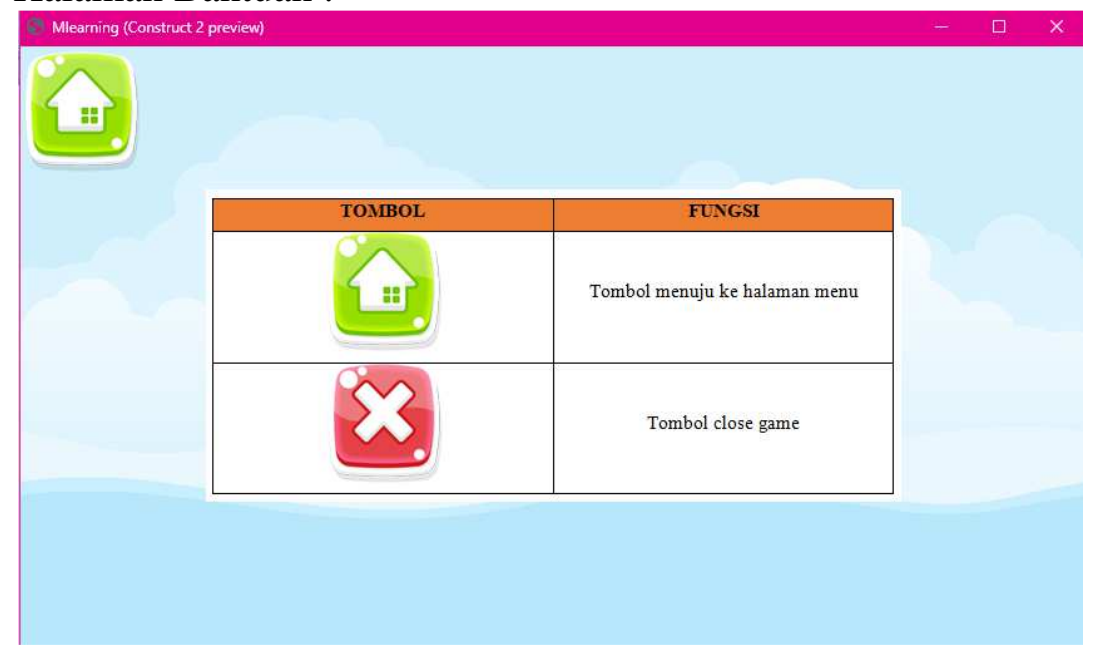

h. Halaman Game : 

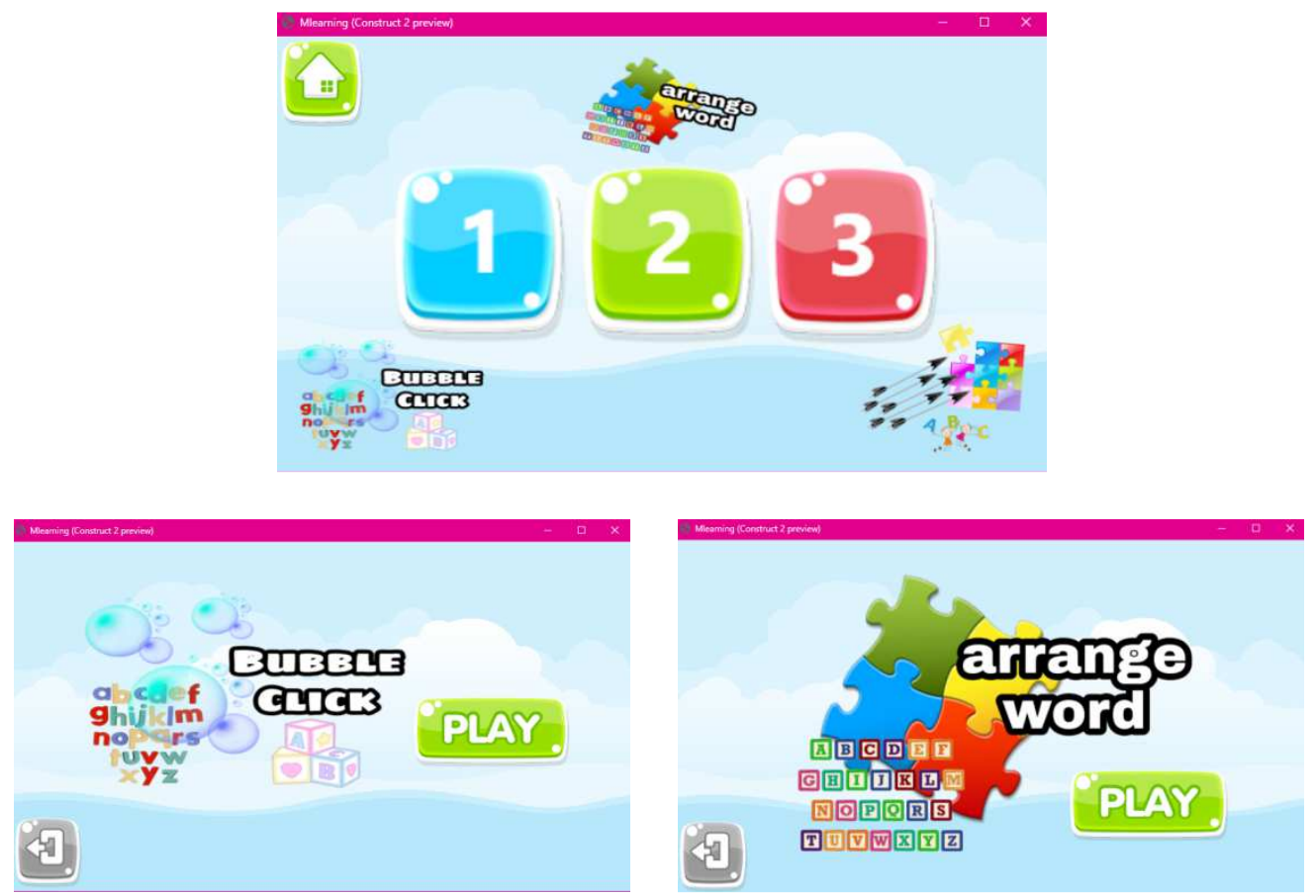

i. Halaman About Me :

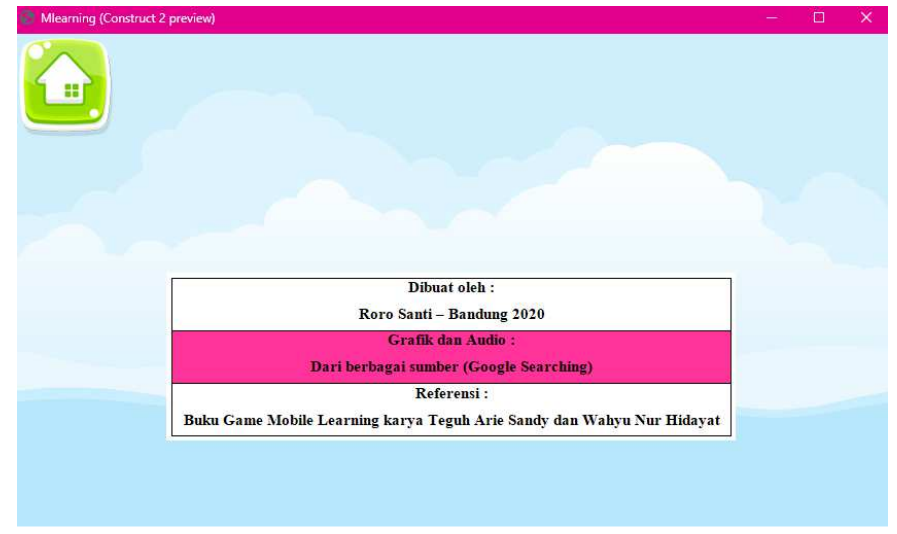

\section{Kesimpulan}

Pemanfaatan aplikasi game, khususnya game edukasi merupakan multimedia learning yang dapat digunakan oleh tenaga pendidik sebagai bahan ajarnya. Untuk memudahkan dan memberikan daya tarik terhadap materi pembelajaran belajar membaca khususnya mengenal huruf. Game ini bisa dimodifikasi untuk belajar berhitung yaitu mengenalkan angka, atau belajar mengaji untuk mengenalkan huruf hijaiyah. Game bubble click yang buat oleh penulis masih berupa perancangan awal sehingga bisa dilakukan modifikasimodifikasi lainnya agar lebih menarik dan lebih besar manfaatnya. Penulis berharap melalui penelitian dan penulisan jurnal ini dapat diambil manfaat bahwa membuat aplikasi tidak tidak harus dilakukan oleh seorang programer saja, namun bisa dilakukan oleh siapa saja khususnya tenaga pendidik dalam membuat perangkat ajar. Sebagai upaya memberikan sosialisasi bahwa membuat aplikasi juga harus mulai dikenalkan dan dijadikan daya tarik bagi anak-anak bangsa. Agar Bangsa Indonesia lebih banyak memiliki developer aplikasi khusunya game yang memiliki ciri dan budaya bangsa serta memajukan bangsa sebagai Tuan Rumah di Negeri Sendiri. 
Akhir kata penulis sebagai pembelajar yang mengajar, sebagai tenaga pendidik bukanlah manusia sempurna namun kita semua harus menjadi figur pembelajar yang unggul karena belajar adalah kebutuhan manusia yang akan terus menerus dilakukan sebagai upaya menghadapi tantangan hidup. Semoga bermanfaat dan berkah untuk kita semua.

\section{Daftar Pustaka}

[1] Agustin, Mubiar. Dr., M.Pd. (2017). Mengajar yang Menyenangkan dan Bermakna Bagi Anak. Edena Ciptawira Mandiri. Bandung

[2] Sandy, Teguh Arie dan Wahyu Nur Hidayat. (2019). Game Mobile Learning. CV. Multimedia Edukasi. Malang.

[3] https://www.scirra.com/construct2/releases

[4] https://www.construct.net/en 